\title{
PENGEMBANGAN MEDIA PEMBELAJARAN VIDEO PRAKTIKUM UNTUK MENINGKATKAN HASIL BELAJAR PESERTA DIDIK
}

\section{Development of Practical Work Video Learning Media to Improve Student Learning Outcomes}

\author{
Tiara Cahaya Putri*, Yatti Sugiarti, Gilang Garnadi Suryadi \\ Program Studi Pendidikan Teknologi Agroindustri \\ Fakultas Pendidikan Teknologi dan Kejuruan, Universitas Pendidikan Indonesia \\ *tiaracahayaputri@upi.edu
}

\begin{abstract}
ABSTRAK
Dasar Proses Pengolahan Hasil Pertanian (DPPHP) merupakan salah satu mata pelajaran produktif di SMK pada program keahlian Agribisnis Pengolahan Hasil Pertanian (APHP) yang memiliki berbagai kompetensi dasar, salah satunya melakukan pengawetan. Berdasarkan studi lapangan yang peneliti laksanakan di SMK PPN Tanjungsari, selama Pembelajaran Jarak Jauh (PJJ) kegiatan praktikum menjadi terhambat, maka dari itu diperlukan media pembelajaran yang dapat membuat peserta didik lebih mudah memahami materi praktikum yang disampaikan, yaitu media pembelajaran berbasis video praktikum. Penelitian ini bertujuan untuk mengetahui pengembangan dan kelayakan, serta pengaruh media pembelajaran video praktikum pada materi melakukan pengawetan terhadap hasil belajar peserta didik. Metode penelitian yang digunakan yaitu kuasi ekperimen dengan desain 4-D (Define, Design, Develop, and Disseminate). Penilaian kelayakan terhadap media video praktikum dilakukan oleh ahli materi dan ahli media yang masing-masing mendapatkan persentase $93.18 \%$ dengan kategori "Sangat Layak" dan 70.19" dengan kategori "Layak". Sampel penelitian terdiri dari 31 orang peserta didik kelompok kontrol dengan media pembelajaran berbasis PowerPoint dan 31 orang peserta didik kelompok eksperimen dengan media pembelajaran berbasis video praktikum. Hasil belajar kognitif peserta didik kelompok eksperimen memiliki nilai rata-rata dan nilai $N$-Gain yang lebih tinggi dibandingkan kelompok kontrol, serta hasil uji statistik menggunakan uji Wilcoxon menunjukan terdapat perbedaan yang signifikan antara hasil belajar peserta didik kelompok eksperimen dan kelas kontrol.
\end{abstract}

Kata kunci: dasar proses pengolahan hasil pertanian (DPPHP), hasil belajar, media pembelajaran powerpoint, media pembelajaran video praktikum, pembelajaran jarak jauh (PJJ).

\begin{abstract}
Basic Process of Agricultural Product Processing is one of the productive subjects in Vocational High School in the Agricultural Product Processing Agribusiness expertise program which has various basic competencies, one of which is preservation. Based on the field study that the researcher carried out at SMK PPN Tanjungsari, during Distance Learning practicum activities were hampered, learning media was needed to make it easier for students to understand the practicum material delivered, namely practicum video-based learning media. This study aims to determine the development and feasibility and the effect of practicum video learning media on the material for preserving student learning outcomes. The research method used is quasi-experimental with a 4-D design (Define, Design, Develop, and Disseminate). The feasibility study on practicum video media was carried out by material experts and media experts who each got a percentage of $93.18 \%$ in the "Very Eligible" category and $70.19 \%$ in the "Eligible" category. The research sample consisted of 31 control group students with PowerPoint-based learning media and 31 experimental group students with practicum video-based learning media. The cognitive learning outcomes of the experimental group students had higher average and $\mathrm{N}$-Gain scores than the control group, and the results of statistical tests using the Wilcoxon test showed that there was a significant difference between the learning outcomes of the experimental group and the control group.
\end{abstract}

Keywords: basic process of agricultural product processing, learning outcomes, power point learning media, practicum video learning media, distance learning. 


\section{PENDAHULUAN}

Kegiatan belajar mengajar di SMK PPN Tanjungsari saat ini dilaksanakan secara daring (dalam jaringan) karena adanya wabah penyakit COVID-19. Pembelajaran daring bisa disebut dengan Pembelajaran Jarak Jauh (PJJ). PJJ adalah pembelajaran dengan menggunakan suatu media yang memungkinkan terjadi interaksi antara pengajar dan pembelajar (Prawiyogi dkk, 2020). PJJ membuat salah satu kegiatan peserta didik di SMK PPN Tanjungsari menjadi terhambat, yaitu pelaksanaan kegiatan praktikum. Maka dari itu diperlukan media pembelajaran yang mudah dipahami supaya materi yang seharusya disampaikan pada saat praktikum tetap didapatkan oleh peserta didik, yaitu media pembelajaran video praktikum.

Media pembelajaran video praktikum dapat membantu peserta didik memahami materi praktikum. Sesuai dengan penelitian Andreas dan Gusmareta (2018) yang menyatakan bahwa penggunaan video praktikum ini praktis dan efektif dimanfaatkan sebagai media pembelajaran. Sudjana dan Rivai (2011) menyebutkan ada beberapa manfaat media video, yaitu; (1) dapat menumbuhkan motivasi; (2) makna pesan akan menjadi lebih jelas, sehingga dapat dipahami oleh peserta didik; dan (3) memungkinkan terjadinya penguasaan dan pencapaian tujuan penyampaian.

Mata pelajaran Dasar Proses Pengolahan Hasil Pertanian (DPPHP) merupakan salah satu mata pelajaran wajib bagi peserta didik kelas X APHP di SMK PPN Tanjungsari, mata pelajaran ini juga termasuk ke dalam mata pelajaran dasar yang harus dikuasai, maka dari itu kegiatan praktikum pada mata pelajaran DPPHP perlu dilakukan atau dapat juga disampaikan melalui suatu media yang menunjang selama PJJ sehingga peneliti tertarik untuk mengembangkan media pembelajaran video praktikum. Menurut penelitian yang dilakukan oleh Lestari dan Maspiyah (2013), penggunaan media video pada proses pembelajaran dapat menunjukan rata-rata nilai posttest peserta didik yang lebih baik dari pretest.

Kelebihan media video praktikum ini yaitu dapat melatih peserta didik untuk mengembangkan daya imajinasi yang abstrak, merangsang partisipasi aktif para peserta didik, menyajikan pesan dan informasi secara serempak bagi seluruh peserta didik, membangkitkan motivasi belajar, mengatasi keterbatasan ruang dan waktu, menyajikan laporan-laporan yang aktual dan orisinil yang sulit dengan menggunakan media lain dan mengontrol arah serta kecepatan belajar peserta didik (Munadi, 2008). Media video praktikum ini merupakan pendekatan media yang tepat untuk menggantikan pengalaman praktikum di laboratorium (Rakhman, dkk., 2017).

Tujuan dari penelitian ini yaitu untuk mengetahui kelayakan video praktikum sebagai media pembelajaran, mengetahui peningkatan hasil belajar peserta didik yang menggunakan media pembelajaran berbasis PowerPoint dan video praktikum, serta untuk mengetahui perbedaan dari hasil belajar peserta didik kelompok kontrol dan kelompok eksperimen.

\section{METODE}

\section{Alat dan Bahan}

Metode yang digunakan pada penelitian ini adalah metode penelitian kuantitatif menggunakan kuasi eksperimen dengan desain penelitian dan pengembangan (research and development/ R\&D) model 4-D yang terdiri dari empat tahap, yaitu tahap pendefinisian (define), tahap perancangan (design), tahap pengembangan (develop), dan tahap penyebaran (dissemination).

Populasi dalam penelitian ini adalah seluruh peserta didik kelas X APHP SMK PPN Tanjungsari sedang mempelajari mata pelajaran Dasar Proses Pengolahan Hasil Pertanian (DPPHP). Teknik pengambilan sampel pada penelitian ini menggunakan cara non-random sampling (sampel tidak acak) dengan teknik sampling jenuh. Adapun sampel yang digunakan yaitu 31 orang peserta didik kelas $X$ APHP 1 sebagai kelompok kontrol dan 31 orang peserta didik kelas X APHP 2 sebagai kelompok eksperimen.

Kelompok eksperimen adalah kelompok dengan pembelajaran menggunakan media pembelajaran video praktikum, sedangkan kelompok kontrol adalah kelompok dengan media pembelajaran konvensional, yaitu PowerPoint. Pada kelompok eksperimen dan kontrol masing-masing diawali dengan pretest dan diakhiri dengan posttest.

Instrumen yang digunakan untuk mengumpulkan data pada penelitian ini adalah angket/kuisioner untuk validasi media pembelajaran video praktikum oleh para ahli dan soal tes dalam bentuk pilihan ganda (PG) sebanyak 10 butir soal untuk pretest dan posttest yang akan diberikan 
kepada seluruh responden peserta didik kelas X APHP.

Prosedur penelitian yang dilaksanakan terdiri dari tahap pendefinisian, tahap perancangan, tahap pengembangan, dan tahap penyebaran. Tahap pendefinisian meliputi kegiatan wawancara dengan guru mata pelajaran untuk mengetahui latar belakang masalah yang ada pada pembelajaran Dasar Proses Pengolahan Hasil Pertanian dan tujuan pembelajaran tersebut. Tahap perancangan meliputi ide pengembangan seperti perancangan materi dalam video, pembuatan naskah, pengambilan gambar (shooting), editing, dan mixing video sehingga menghasilkan video prototype. Tahap pengembangan terdiri dari validasi butir soal oleh guru mata pelajaran, validasi kelayakan video oleh ahli materi dan ahli media, revisi oleh peneliti, produksi akhir media pembelajaran video praktikum, dan uji coba pada 10 orang peserta didik kelas XI APHP. Tahap penyebaran video praktikum dilakukan untuk pengambilan data pada seluruh responden kelas X APHP untuk mengetahui hasil belajar peserta didik setelah penerapan media pembelajaran video praktikum. Prosedur penelitian dapat dilihat pada Gambar 1.

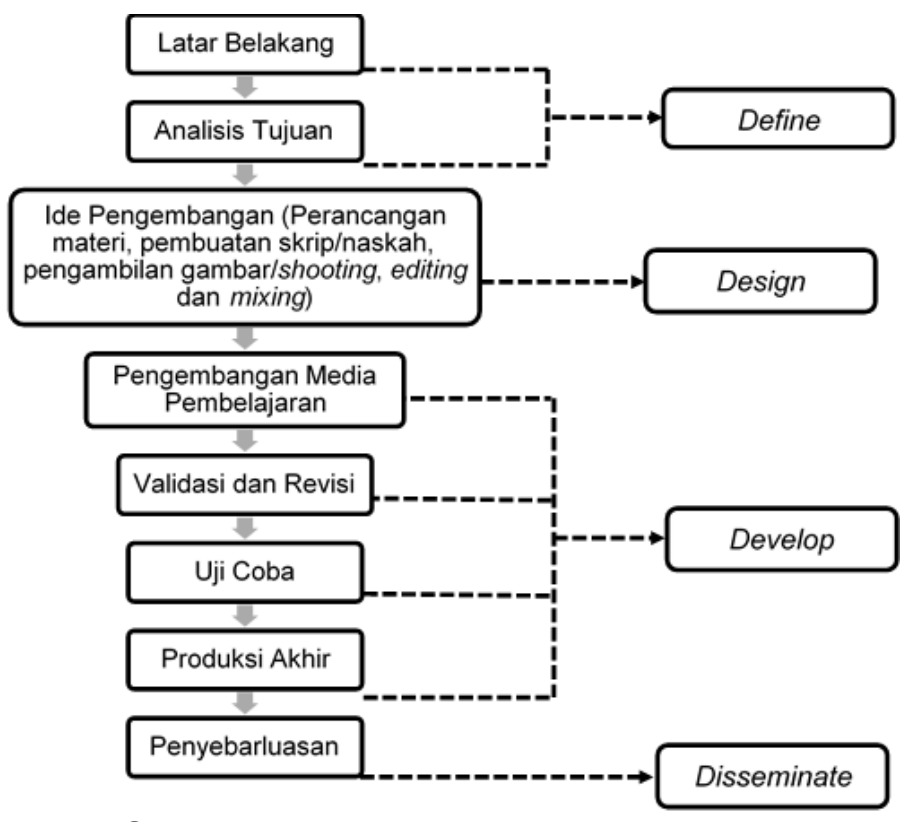

Gambar 1. Prosedur Penelitian

Sumber: Krismanto (2016)

\section{Analisis Data Lembar Validasi Uji Kelayakan}

Instrumen yang digunakan untuk mengetahui kelayakan produk video praktikum ini berupa kuisioner yang ditujukan kepada ahli media, ahli materi, dan partisipan uji terbatas, yaitu 10 orang peserta didik kelas XI APHP di SMK PPN Tanjungsari. Peneliti menggungakan metode statistik kuantitatif yang dihitung dalam bentuk distribusi skor dan persentase setiap instrumen. Perhitungan masing-masing validasi menggunakan rumus:

$$
\text { Persentase }(\%)=\frac{\text { Total skor yang diperoleh }}{\text { Total maksimum }} \times 100 \%
$$

Kuisioner dibuat dengan menggunakan rating scale yang memiliki empat kriteria jawaban. Keempat kriteria jawaban tersebut memiliki skor dan kriteria yang terdapat pada Tabel 1.

Tabel 1. Skor dan Kriteria Penilaian Kelayakan Media

\begin{tabular}{ll}
\hline Rating Scale & Kriteria \\
\hline 4 & Sangat Baik \\
3 & Baik \\
2 & Kurang Baik \\
1 & Tidak Baik \\
\hline
\end{tabular}

Instrumen untuk validasi kuisioner kelayakan video praktikum terdiri dari empat penilaian yang ada pada Tabel 1. Kategori untuk validasi kuisioner dapat disusun sebagai berikut: 


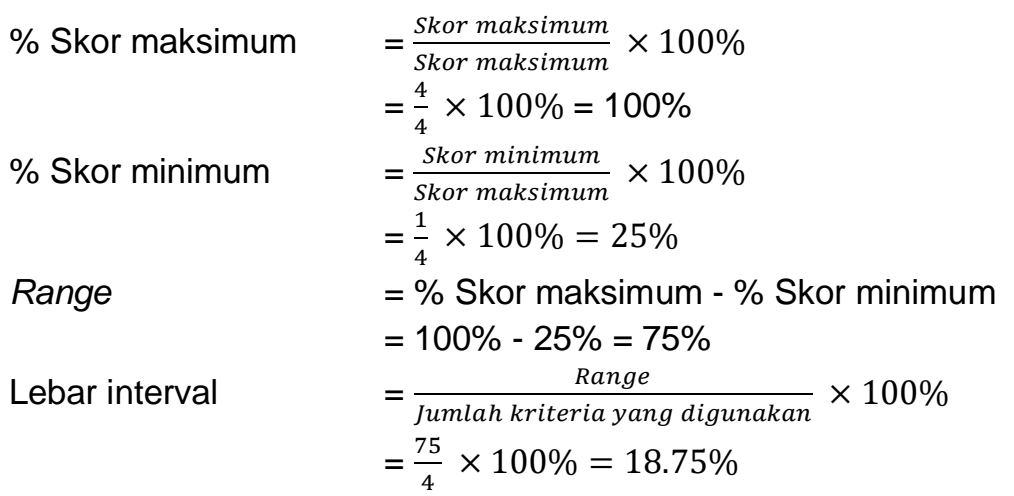

2.

Berdasarkan hasil perhitungan di atas, data hasil validasi dapat diinterpretasikan pada Tabel

Tabel 2. Kategori Hasil Validasi

\begin{tabular}{ll}
\hline Persentase (\%) & Hasil Konversi \\
\hline $\mathrm{X} \geq 81.26$ & Sangat Layak \\
$62.51 \leq \mathrm{X} \leq 81.25$ & Layak \\
$43.76 \leq \mathrm{X} \leq 62.50$ & Tidak Layak \\
$25 \leq \mathrm{X} \leq 43.75$ & Sangat Tidak Layak \\
\hline \multicolumn{1}{c}{ Validasi dilakukan pada hari Rabu 02 Juni 2021 oleh ahli materi dan ahli media secara daring }
\end{tabular}

Validasi dilakukan pada hari Rabu, 02 Juni 2021 oleh ahli materi dan ahli media secara daring. Hasil analisis lembar validasi ahli materi menunjukan dari seluruh aspek bahwa prototype media pembelajaran video praktikum sangat layak untuk digunakan namun dengan beberapa revisi, sedangkan hasil analisis lembar validasi ahli media menunjukan dari seluruh aspek bahwa prototype media pembelajaran video praktikum layak untuk digunakan dengan beberapa revisi.

\section{Analisis Data Validasi Butir Soal}

Instrumen yang digunakan untuk mengetahui validitas butir soal pretest dan posttest ini berupa kuisioner yang ditujukan kepada guru mata pelajaran Dasar Proses Pengolahan Hasil Pertanian (DPPHP). Rentang skor yang diberikan yaitu 1 dan 0 . Batasan kategori butir soal dapat disusun sebagai berikut:

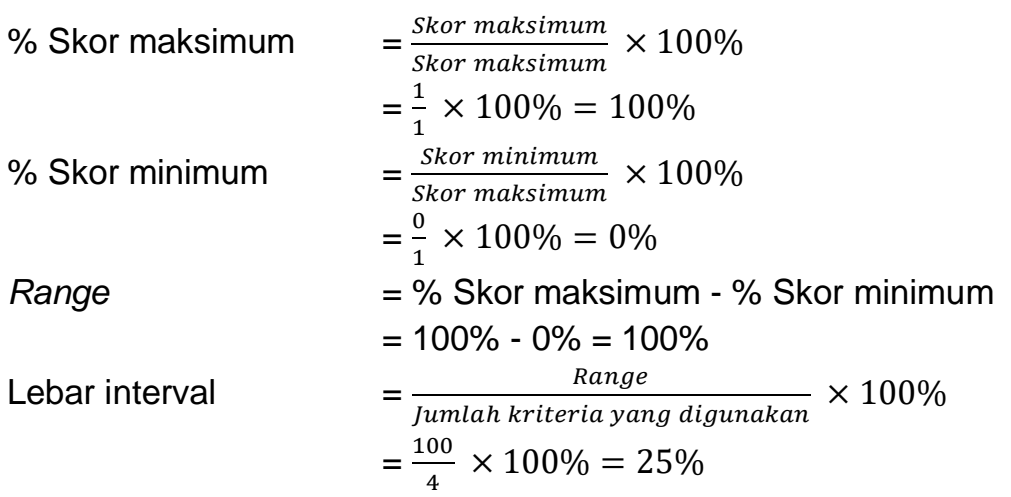

Berdasarkan hasil perhitungan di atas, data hasil validasi dapat diinterpretasikan pada Tabel 3.

Tabel 3. Kategori Hasil Validasi Butir Soal

\begin{tabular}{ll}
\hline \multicolumn{1}{c}{ Persentase (\%) } & Interpretasi \\
\hline $\mathrm{X} \geq 75$ & Sangat Layak \\
$50 \leq \mathrm{X}<75$ & Layak \\
$25 \leq \mathrm{X}<50$ & Tidak Layak \\
$\mathrm{X}<25$ & Sangat Tidak Layak \\
\hline
\end{tabular}

3. Analisis Hasil Belajar Peserta Didik

a. Menghitung nilai rata-rata dan $\mathrm{N}$-Gain

Pretest dan posttest diberikan masing-masing 10 butir soal tentang melakukan pengawetan yang bernilai 1 jika jawaban benar dengan skor maksimal 100 yang dapat dimaksukan dengan rumus:

$$
\text { Nilai }=\frac{\sum \text { Jawaban benar }}{\text { Jumlah soal }} \times 100
$$

Data diolah menggunakan Microsoft Excel untuk menghitung skor pretest dan posttest. Nilai diperoleh menggunakan rumus (Trianto, 2010): 


$$
N t=\frac{\sum \text { Hasil nilai peserta didik }}{\sum \text { Peserta didik }} \times 100
$$

$\mathrm{Nt}$ merupakan nilai rata-rata soal yang dijawab benar. Nilai rata-rata yang diperoleh dapat diinterpretasikan pada Tabel 4.

Tabel 4. Konversi Nilai Kognitif

\begin{tabular}{lll}
\hline Intervensi Nilai & Kategori & Kriteria \\
\hline $81-100$ & A & Sangat Baik \\
$61-80$ & B & Baik \\
$41-60$ & C & Cukup Baik \\
$21-40$ & D & Kurang Baik \\
\hline
\end{tabular}

Sumber: Tampubolo (2014)

Untuk mengetahui efektivitas peningkatan hasil belajar peserta didik dapat diketahui dengan perhitungan Normalized Gain (N-Gain) dengan rumus berikut:

$$
\text { Gain }=\frac{\text { skor post test }- \text { skor pre test }}{\text { skor maksimum }- \text { skor pre test }}
$$

Perolehan skor $\mathrm{N}$-Gain dikategorikan ke dalam tiga kategori yang ditunjukan pada Tabel 5 .

Tabel 5. Kriteria Perolehan Skor N-Gain

\begin{tabular}{ll}
\hline Skor $\mathbf{N}$-Gain & Kriteria $\mathbf{N}$-Gain \\
\hline $\mathrm{N}-$ Gain $>0.70$ & Tinggi \\
$0.30 \leq \mathrm{N}-$ Gain $\leq 0.70$ & Sedang \\
$\mathrm{N}-$ Gain $<0.30$ & Rendah \\
\hline
\end{tabular}

b. Uji Statistik

Uji statistik yang dilakukan pada penelitian ini meliputi uji normalitas, uji homogenitas, dan uji beda dengan bantuan perangkat lunak SPSS versi 24. Data yang diuji adalah nilai hasil belajar peserta didik pada pretest dan posttest kelompok kontrol dan juga kelompok eksperimen. Uji normalitas dilakukan dengan menggunakan uji Shapiro-Wilk, sedangkan uji homogenitas menggunakan uji Levene. Jika hasil uji normalitas menunjukan data yang berdistribusi normal, maka pengujian dapat dilanjutkan dengan uji independent sample $t$-test, namun jika hasil uji normalitas menunjukan data yang tidak berdistribusi normal, maka pengujian dilanjutkan dengan uji non-parametrik yaitu uji Wilcoxon.

\section{HASIL DAN PEMBAHASAN}

\section{Pengembangan Video Praktikum sebagai Media Pembelajaran}

a. Hasil

Pengembangan video praktikum yang dilaksanakan menghasilkan video praktikum yang telah melewati validasi kelayakan oleh para ahli dan uji coba oleh peserta didik kelas XI APHP. Data diperoleh menggunakan angket/kuisioner yang diberikan secara daring dalam bentuk Google Form yang dibagikan melalui personal chat. Pengisian lembar validasi oleh para ahli dilaksanakan pada hari Senin, 31 Mei 2021 dan Rabu, 02 Juni 2021, sedangkan uji coba dilaksanakan pada hari Rabu, 09 Juni 2021. Hasil analisis data validasi dan uji coba masing-masing dapat dilihat pada Tabel 6 , Tabel 7, dan Tabel 8.

Tabel 6. Data Hasil Validasi Ahli Materi

\begin{tabular}{cccc}
\hline No & Aspek Penilaian & Persentase (\%) & Kriteria \\
\hline 1. & Kualitas materi & 93.75 & Sangat Layak \\
2. & Kemanfaatan materi & 92.86 & Sangat Layak \\
\hline & Rata-rata & 93.18 & Sangat Layak \\
\hline
\end{tabular}

Tabel 7. Data Hasil Validasi Ahli Media

\begin{tabular}{clcc}
\hline No & Aspek Penilaian & Persentase (\%) & Kriteria \\
\hline 1. & Kualitas media & 68.75 & Layak \\
2. & Penggunaan bahasa & 71.43 & Layak \\
3. & Layout media & 71.43 & Layak \\
\hline
\end{tabular}


Tiara Cahaya Putri, Yatti Sugiarti, Gilang Garnadi Suryadi / EDUFORTECH 6 (2) 2021

\begin{tabular}{cccc}
\hline & Rata-rata & 70.19 & Layak \\
\hline & & Tabel 8. Skor Uji Coba & \\
\hline No & Aspek Penilaian & Persentase (\%) & Kriteria \\
\hline 1. & Tampilan & 91.88 & Sangat Layak \\
2. & Pengoperasian & 93.75 & Sangat Layak \\
3. & Kemanfaatan & 92.50 & Sangat Layak \\
\hline
\end{tabular}

Persentase pada aspek penilaian kualitas materi yaitu sebesar $93.75 \%$ dan pada aspek penilaian kemanfaatan materi sebesar $92.86 \%$. Secara keseluruhan, tingkat validasi materi pada media pembelajaran video praktikum yang telah dibuat memperoleh persentase rata-rata sebesar $93.18 \%$. Berdasarkan Tabel 3.7 kategori hasil penilaian kelayakan media, dapat disimpulkan bahwa materi yang terdapat pada media pembelajaran video praktikum ini masuk kedalam kategori "Sangat Layak".

Persentase pada aspek penilaian kualitas media yaitu sebesar $68.75 \%$, pada aspek penilaian penggunaan bahasa sebesar $71.43 \%$, dan pada aspek penilaian layout media memperoleh $71.43 \%$. Secara keseluruhan, tingkat validasi media pada media pembelajaran video praktikum yang telah dibuat persentase rata-rata sebesar $70.19 \%$. Berdasarkan Tabel 3.7 kategori hasil penilaian kelayakan media, dapat disimpulkan bahwa materi yang terdapat pada media pembelajaran video praktikum ini masuk kedalam kategori "Layak".

Dari kedua penilaian oleh para ahli, dapat disimpulkan bahwa kelayakan media pembelajaran video praktikum sudah dapat digunakan setelah revisi. Revisi yang dikerjakan berdasarkan saran yang disampaikan oleh responden ahli materi dan ahli media. Gambar 2 merupakan cuplikan tampilan media pembelajaran video praktikum setelah direvisi.

Sebelum revisi:

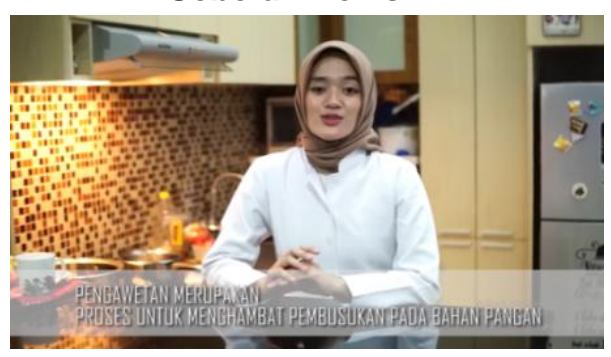

Setelah revisi:

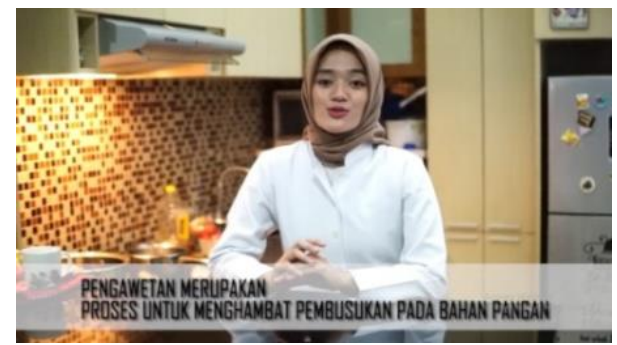

a) Tampilan awal video sebelum dan setelah revisi, font color diubah menjadi warna hitam agar terlihat jelas.
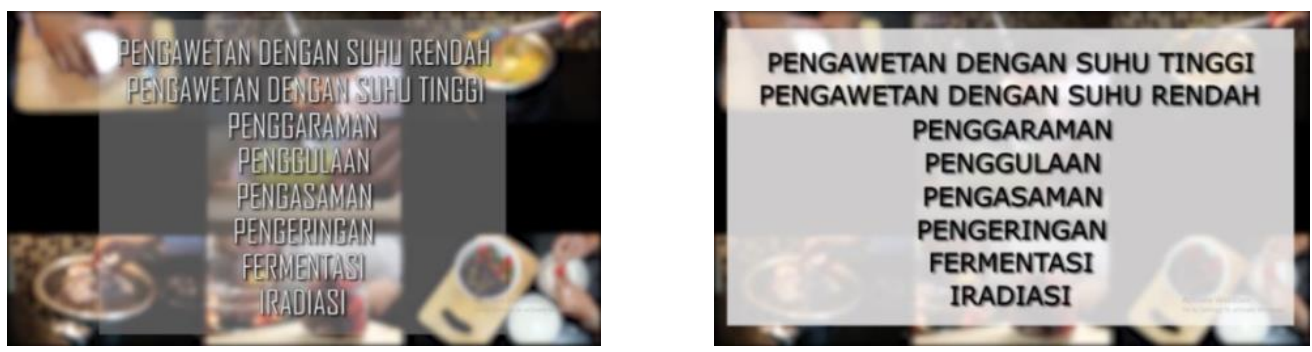

b) Cuplikan materi tentang teknik-teknik pengawetan, font color dan shading paraghraph diubah menjadi warna yang dapat membantu tulisan terlihat jelas.
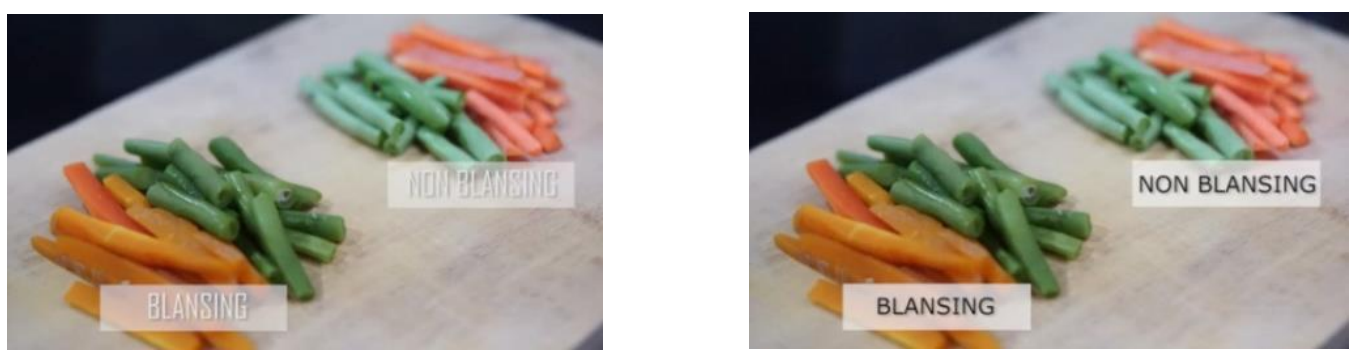

c) Perbandingan hasil pangan yang diberi perlakuan, font color dan shading paraghraph diubah menjadi warna yang dapat membantu tulisan terlihat jelas. 

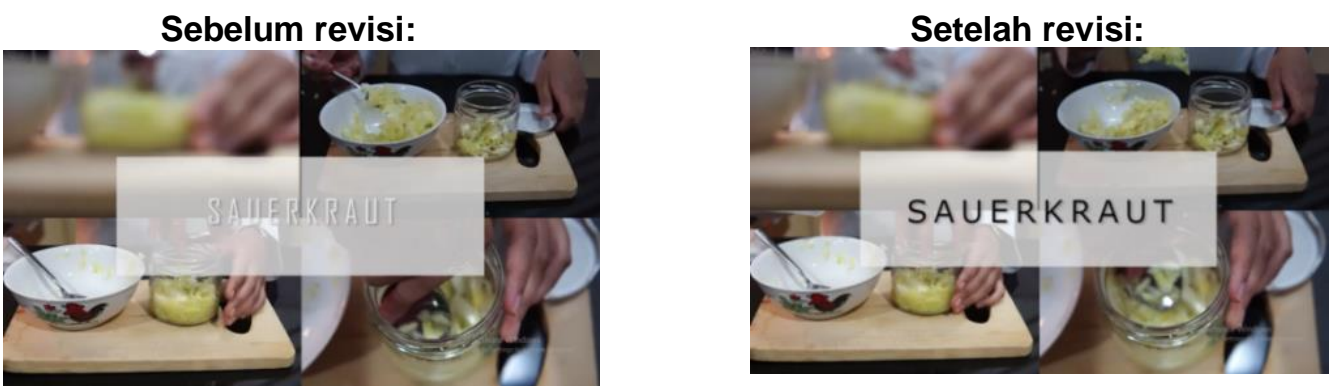

d) Cuplikan video tutorial pembuatan sauerkraut, font color diubah menjadi warna hitam agar terlihat jelas.

\section{Gambar 2. Cuplikan Tampilan Video Sebelum dan Setelah Revisi}

\section{b. Pembahasan}

Video pembelajaran merupakan media pembelajaran yang digunakan pada proses pembelajaran yang bertujuan untuk membnatu guru maupun siswa dalam mengikuti proses belajar, khususnya pada pelaksanaan praktikum. Selain digunakan oleh guru saat proses pembelajaran, media video praktikum juga dapat dimanfaatkan oleh peserta didik kapan saja dan dimana saja jika diperlukan. Pengembangan media pembelajaran video praktikum pada penelitian ini menggunakan metode pengembangan 4-D yang terdiri dari beberapa tahapan, yaitu tahap pendefinisian, tahap perancangan, tahap pengembangan, dan tahap penyebaran.

Sesuai dengan Riyana (2007), bahwa karakteristik video pembelajaran yaitu media pembelajaran harus mampu menarik minat peserta didik, mengikuti perkembangan zaman, mampu memanipulasi gambar, tidak bergantung pada media lain, menggunakan resolusi tinggi, mudah diakses, dan dapat digunakan secara klasikal maupun individual. Maka dari itu video praktikum yang telah diproduksi dan diujicobakan terhadap peserta didik kelas XI APHP mendapatkan kriteria keseluruhan "Sangat Layak".

\section{Hasil Belajar Peserta Didik Kelompok Kontrol dan Kelompok Eksperimen}

a. Hasil

Pembelajaran dilaksanakan pada hari Jum'at, 11 Juni 2021 secara daring (dalam jaringan) melalui WhatsApp Group. Kelompok kontrol dan kelompok eksperimen masing-masing terdiri dari 31 orang peserta didik, sehingga total peserta didik ada 62 orang. Media pembelajaran yang digunakan yaitu media pembelajaran berbasis PowerPoint untuk kelompok kontrol dan media pembelajaran video praktikum untuk kelompok eksperimen.

Pretest dilakukan di kelompok kontrol dan kelompok eksperimen pada awal pertemuan sebelum diberikan materi pembelajaran untuk mengukur pengetahuan awal peserta didik terhadap materi yang akan disampaikan yaitu mengenai melakukan pengawetan. Sedangkan posttest dilakukan setelah kedua kelas selesai diberikan perlakuan dengan masing-masing kelompok kontrol dan kelompok eksperimen menggunakan media pembelajaran PowerPoint dan video praktikum.

1) Nilai Rata-rata dan Normalized Gain

Hasil belajar peserta didik dianalisis berdasarkan nilai pretest dan posttest yang didapatkan oleh setiap peserta didik. Gambar 3 menunjukan nilai rata-rata hasil belajar peserta didik kelompok kontrol dan kelompok eksperimen. 
Tiara Cahaya Putri, Yatti Sugiarti, Gilang Garnadi Suryadi / EDUFORTECH 6 (2) 2021

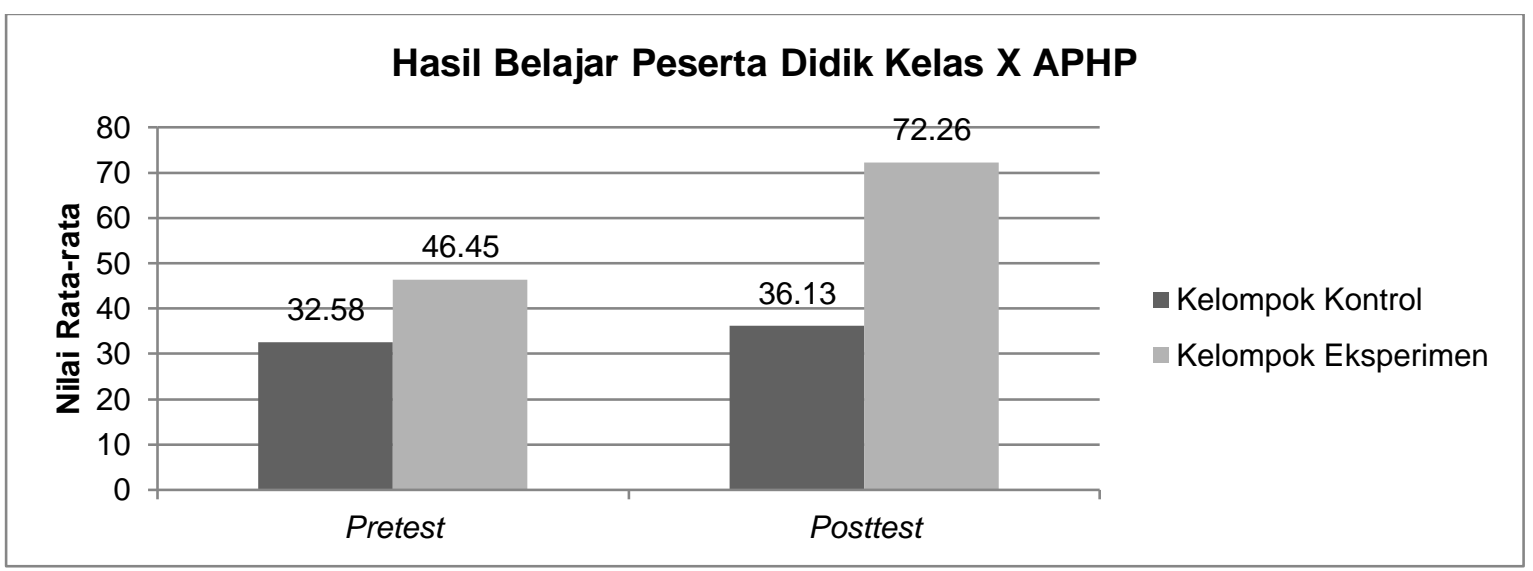

Gambar 3. Nilai Rata-rata Hasil Belajar Peserta Didik

Hasil perhitungan normalized gain pada kelompok kontrol dan kelompok eksperimen dapat dilihat pada Gambar 4.

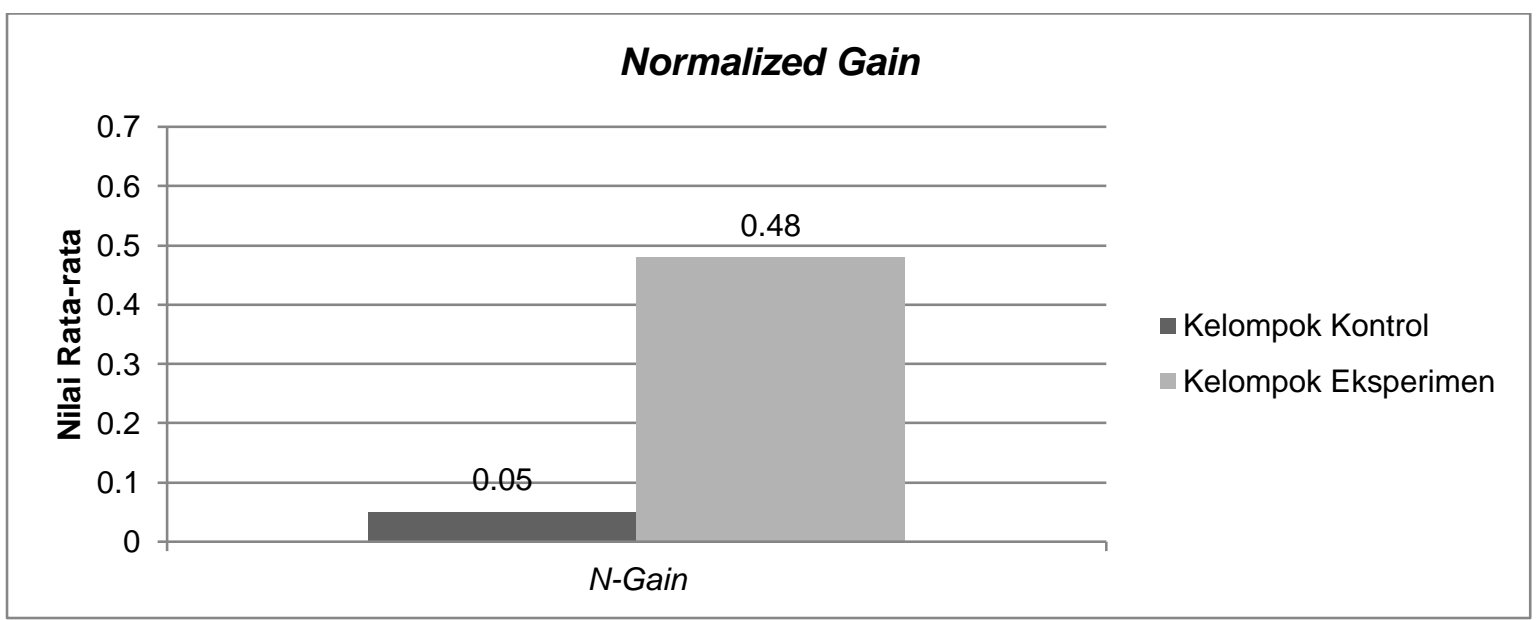

Gambar 4. Nilai N-Gain Peserta Didik

2) Uji Statistik

Hasil uji normalitas, uji homogenitas, dan uji non-parametrik Wilcoxon berdasarkan nilai pretest dan posttest peserta didik kelompok kontrol dan kelompok eksperimen dapat dilihat pada Tabel 9.

Tabel 9. Hasil Uji Statistik Nilai Prestest dan Posttest Kelompok Kontrol dan Kelompok Eksperimen

\begin{tabular}{cccccc}
\hline \multirow{5}{*}{ Pretest } & Kelompok & $\begin{array}{c}\text { Jumlah } \\
\text { Sampel }\end{array}$ & Uji Normalitas & Uji Homogenitas & $\begin{array}{c}\text { Uji } \\
\text { Non-parametrik }\end{array}$ \\
\cline { 2 - 6 } Posttest & Kontrol & 31 & 0.063 & 0.080 & 0.316 \\
& Eksperimen & 31 & 0.126 & & \\
& Kontrol & 31 & 0.037 & 0.068 & 0.000 \\
& Eksperimen & 31 & 0.015 & & \\
\hline
\end{tabular}

Berdasarkan Tabel 9 dapat diketahui bahwa pada hasil uji normalitas menunjukan nilai signifikansi (Sig.) dari pretest kedua kelompok $>\alpha(0.05)$, sehingga data tersebut berdistribusi normal. Sedangkan hasil uji normalitas menunjukkan nilai signifikansi (Sig.) dari posttest kedua kelompok $<\alpha$ (0.05), sehingga data tersebut tidak berdistribusi normal. Oleh karena itu dapat disimpulkan bahwa $\mathrm{H}_{0}$ ditolak atau data tidak berdistribusi normal.

Selanjutnya hasil uji homogenitas yang menunjukan nilai signifikansi (Sig.) dari kedua kelompok $>\alpha(0.05)$, maka dapat disimpulkan bahwa $\mathrm{H}_{0}$ diterima atau variansi data pada tiap kelompok homogen.

Uji beda yang dilakukan menggunakan uji non-parametrik karena data dari uji normalitas tidak berdistribusi normal (Oktaviani dan Norobroto, 2014). Uji non-parametrik yang menjadi alternatif dari uji paired sample t-test ini yaitu uji Wilcoxon. Berdasarkan hasil yang didapatkan pada uji Wilcoxon, 
diketahui Asymp. Sig. (2-tailed) pada kelompok kontrol memiliki nilai yang lebih besar dari nilai t-kritis yaitu 0.05 sehingga dapat ditulis [Asymp. Sig. (2-tailed) 0.316] > [t-kritis 0.05]. Sedangkan nilai Asymp. Sig. (2-tailed) pada kelompok eksperimen memiliki nilai ini lebih kecil dari nilai t-kritis yaitu 0.05 sehingga dapat ditulis [Asymp. Sig. (2-tailed) 0.0000] $<$ (t-kritis 0.05).

Dapat disimpulkan bahwa uji Wilcoxon ini menunjukan adanya perbedaan pada hasil belajar peserta didik yang menggunakan media pembelajaran PowerPoint dan media video praktikum, lebih tepatnya media pembelajaran video praktikum yang sedang dikembangkan berpengaruh terhadap hasil belajar peserta didik.

b. Pembahasan

Hasil belajar adalah ukuran atau tingkat keberhasilan yang dapat dicapai oleh seorang peserta didik berdasarkan pengalaman yang diperoleh setelah dilakukan evaluasi dan biasanya diwujudkan dengan nilai atau angka tertentu serta menyebabkan terjadinya perubahan yang meliputi aspek kognitif, afektif, dan psikomotor (Wulandari, 2013). Hasil belajar yang didapatkan pada penelitian ini meliputi hasil belajar pada aspek kognitif yang dihasilkan dari nilai pretest dan posttest.

Pelaksanakan pembelajaran dilaksanakan sesuai dengan Rencana Pelaksanaan Pembelajaran yang telah dibuat. Pada kelompok kontrol dilakukan dengan metode ceramah yang dipadukan dengan metode diskusi atau biasa disebut dengan model pembelajaran konvensional yang menggunakan media pembelajaran PowerPoint. Model pembelajaran konvensional merupakan model pembelajaran yang biasa diterapkan oleh guru yang pada umumnya terdiri dari metode ceramah, tanya jawab, dan pemberian tugas (Peranginangin, 2020). Sedangkan pada kelompok eksperimen dilakukan dengan metode modern yang menekankan pada konsep-konsep baru dan media yang digunakan lebih modern, yaitu media pembelajaran video praktikum.

Soal pretest dan posttest telah divalidasi terlebih dahulu oleh ahli materi yang selanjutnya diberikan kepada peserta didik kelas X APHP. Hasil belajar peserta didik dapat dilihat pada Gambar 3. Hasil posttest peserta didik setelah diberikan perlakuan dengan media pembelajaran PowerPoint masuk kedalam kriteria kurang baik, sedangkan pada perlakuan dengan media pembelajaran video praktikum masuk kedalam kriteria baik. Maka dari itu sesuai dengan nilai rata-rata $\mathrm{N}$-Gain peserta didik kelompok kontrol dapat dikatakan bahwa rata-rata efektivitas peningkatan hasil belajar peserta didik kelas kontrol rendah, sedangkan pada peserta didik kelompok eksperimen dapat dikatakan sedang. Maka dari itu efektivitas peningkatan hasil belajar peserta didik sebelum dan sesudah pembelajaran dengan menggunakan media pembelajaran yang dikembangkan lebih efektif pada pembelajaran menggunakan media video praktikum.

Menurut Syarifuddin (2011), faktor yang memengaruhi hasil belajar peserta didik dibagi kedalam dua faktor, yaitu faktor internal dan faktor eksternal. Faktor internal diantaranya kondisi jasmani dan rohani peserta didik, kecerdasan, minat, latihan dan kebiasaan belajar, motivasi pribadi dan konsep diri, serta kemandiriian. Faktor eksternal diantaranya model pembelajaran, kondisi keluarga, guru dan cara mengajarnya, kesempatan yang tersedia, dan motivasi sosial.

Adapun hasil uji normalitas dan uji homogenitas nilai pretest posttest pada penelitian ini menunjukkan bahwa data tidak berdistribusi normal dan homogen. Maka dari itu pengujian dilanjutkan dengan uji non-parametrik Wilcoxon. Hasil uji non-parametrik ini dapat dilihat pada Tabel 9 yang menunjukkan bahwa nilai Asym. Sig. (2-tailed) memiliki nilai $<0.05$, ini menunjukan adanya perbedaan pada hasil belajar peserta didik yang menggunakan media pembelajaran PowerPoint dan media video praktikum, lebih tepatnya media pembelajaran video praktikum yang sedang dikembangkan berpengaruh terhadap hasil belajar peserta didik.

\section{KESIMPULAN}

Berdasarkan hasil penelitian dan pembahasan, maka dapat diambil simpulan sebagai berikut:

1. Media pembelajaran berbasis video praktikum dikembangkan dengan mengacu pada model pengembangan 4-D (Define, Design, Develop, and Disseminate). Video praktikum yang telah diproduksi memeroleh kategori "Sangat Layak" dalam segi materi, "Layak" dalam segi media, dan "Sangat Layak" dalam segi penggunaan saat uji coba.

2. Hasil belajar yang diperoleh kelompok kontrol dari pretest posttest masing-masing termasuk dalam kategori "Kurang Baik" dan mendapatkan nilai $N$-Gain "Rendah", sehingga dapat diartikan bahwa 
peserta didik kelompok kontrol kurang memahami materi yang disampaikan menggunakan media pembelajaran berbasis PowerPoint.

3. Hasil belajar yang diperoleh kelompok eksperimen dari pretest posttest masing-masing termasuk dalam kategori "Cukup Baik" dan "Baik", nilai N-Gain yang didapatkan masuk dalam kategori "Sedang", sehingga dapat diartikan bahwa peserta didik kelompok eksperimen lebih memahami materi yang disampaikan menggunakan media pembelajaran berbasis video praktikum dibandingkan dengan media pembelajaran berbasis PowerPoint.

4. Media pembelajaran video praktikum berpengaruh terhadap peningkatan hasil belajar kognitif peserta didik kelas X APHP pada materi "Melakukan Pengawetan".

\section{DAFTAR PUSTAKA}

Andreas, L. O., dan Gusmareta, Y. (2018). Pengembangan Media Pembelajaran Mata Kuliah Mekanika Tanah dan Teknik Pondasi Berbasis Video Tutorial. CIVED (Journal of Civil Engineering and Vocational Education), 5(4), 1-6.

Krismanto, D. A. (2016). Pengembangan Media Pembelajaran Berbasis Video Tutorial Gerak Dasar Tenis Lapangan untuk Anak Tingkat Sekolah Dasar di Sekolah Tenis Kabupaten Temanggung. (Skripsi). Yogyakarta: UNY Yogyakarta.

Munadi, Y. (2008). Media Pembelajaran (Sebuah Pendekatan Baru). Jakarta: Bumi Aksara.

Oktaviani, M. A., dan Notobroto, H. B. (2014). Perbandingan Tingkat Konsistensi Normalitas Distribusi Metode Kolmogorov-Smirnov, Lilliefors, Shapiro-Wilk, dan Skewness-Kurtosis. Jurnal Biometrika dan Kependudukan, 3(2), 127-135.

Peranginangin, A. (2020). Perbedaan Hasil Belajar Siswa yang Diajar dengan Model Pembelajaran Elaborasi dengan Model Pembelajaran Konvensional. Jurnal Penelitian Fisikawan, 3(1), 43-50.

Prawiyogi, A. G., Purwanugraha, A., Fakhry, G., dan Firmansyah, M. (2020). Efektivitas Pembelajaran Jarak Jauh Terhadap Pembelajaran Siswa di SDIT Cendekia Purwakarta. JPD - Jurnal Pendidikan Dasar, 11(1): 94-101.

Rakhman, K. A., Saraha, A. R., dan Sugrah, N. (2017). Pengembangan Video Penggunaan Alat Gelas Laboratorium Kimia di Universitas. Jurnal Inovasi Pendidikan IPA, 3(2), 161-171.

Riyana, C. (2007). Pedoman Pengembangan Media Video. Jakarta: P3AI UPI.

Sudjana, N., dan Rivai, A. (2011). Media Pengajaran. Bandung: Sinar Baru Algensindo.

Sugiyono. (2016). Metode Penelitian Pendidikan, Pendekatan Kuantitatif, Kualitatif, dan R\&D. Bandung: Alfabeta.

Susanto, J. (2012). Pengembangan Perangkat Pembelajaran Berbasis Lesson Study dengan Kooperatif Tipe Numberhead Together untuk Meningkatkan Aktivitas dan Hasil Belajar IPA di SD. Journal of Primary Educational, 1(2), 75.

Syarifuddin, A. (2011). Penerapan model pembelajaran cooperative belajar dan faktor-faktor yang mempengaruhinya. Ta'dib: Jurnal Pendidikan Islam, 16(01), 113-136.

Tampubolo, S. M. (2014). Penelitian Tindakan Kelas sebagai Pengembangan Profesi Pendidikdan Keilmuan. Jakarta: Erlangga.

Trianto. (2010). Model Pembelajaran Terpadu, Konsep, Strategi, dan Implementasinya dalam KTSP. Jakarta: Bumi Aksara.

Wulandari, B. (2013). Pengaruh Problem-Based Learning terhadap Hasil Belajar Ditinjau dari Motivasi Belajar PLC di SMK. Jurnal Pendidikan Vokasi, 3(2), 78-180. 